\title{
The Evaluation of the Deaths Related to Hypothermy in Eskisehir between 1997 and 2016
}

\author{
Karbeyaz $\mathrm{K}^{1^{*}}$, Adnan $\mathrm{C}^{2}$, Emrah $\mathrm{E}^{3}$ and Gulsum $\mathrm{OE}^{4}$ \\ ${ }^{1}$ Forensic Medicine, Eskisehir Osmangazi University, Eskisehir, Turkey \\ ${ }^{2}$ Mustafa Kemal University Faculty of Medicine Department of Forensic Medicine, Hatay, Turkey \\ ${ }^{3}$ Council of Forensic Medicine, Eskisehir Branch Manager Eskisehir, Turkey \\ ${ }^{4}$ Eskişehir Osmangazi University Faculty of Medicine Department of Public Health, Eskisehir, Turkey
}

"Corresponding author: Kenan Karbeyaz, Forensic Medicine, Eskisehir Osmangazi University, Millet Street, Eskisehir 26040, Turkey, Tel: 5052230885; E-mail: drkenankarbeyaz@hotmail.com

Received date: May 22, 2017; Accepted date: June 12, 2017; Published date: June 14, 2017

Copyright: (c) 2017 Karbeyaz K. This is an open-access article distributed under the terms of the Creative Commons Attribution License, which permits unrestricted use, distribution, and reproduction in any medium, provided the original author and source are credited.

\begin{abstract}
Introduction: In this study, it was aimed to investigate the frequency of autopsy findings and the frequency of cases decided to die due to hypothermia in Eskişehir.

Materials and Method: This study is a descriptive study conducted in the 20-year period between 1997 and 2016 in Eskişehir province by retrospective examination of case files belonging to judicial qualifications. These deaths were included in the study because of the decision to die due to hypothermia. The cases were evaluated in terms of age, gender, location of the body, month in which the body was found, autopsy findings, psychiatric disease history, toxicological examination and death investigation information.

Findings: It has been determined that in 20 year period, there were 16 deaths due to hypothermia in Eskişehir, Turkey. All cases were male and mean age (SD) was $62.4 \pm 7.2$ years. Wischnewsky ulcers occurred in 11 cases $(68.8 \%)$ due to hypothermia. 9 cases $(56.3 \%)$ had a history of psychiatric and neurological disease.

Conclusion: Hypothermic deaths are preventable deaths and precautions should be taken to protect against hypothermia in elderly people, homeless people and those with mental illness that will affect the state of consciousness.
\end{abstract}

Keywords: Hypothermia; Death; Eskisehir; Forensic medicine

\section{Introduction}

Hypothermia is the temperature of the body falling below $35^{\circ} \mathrm{C}$ Clinically, there are 3 groups: The range between $32^{\circ} \mathrm{C}$ and $35^{\circ} \mathrm{C}$ is classified as mild, between $28^{\circ} \mathrm{C}$ and $32^{\circ} \mathrm{C}$ as moderate and below $28^{\circ} \mathrm{C}$ as severe. According to etiological cause, it is classified as primary and secondary hypothermia. Primary hypothermia is caused by the exposure of the healthy individual to cold. Secondary hypothermia is defined as heat regulation disorder due to an underlying clinical condition such as chronic diseases, poisoning and advanced age [1-4].

Primary hypothermic cases are encountered more frequently in forensic medicine practice [5]. Despite all the developments in forensic medicine and forensic sciences, hypothermia-related deaths are still among the most difficult cases of postmortem diagnosis in forensic medicine practice. Hypothermic death is diagnosed by excision of other possible causes of death in addition to macroscopic and microscopic findings [6]. Cold skin erythema in the external examination, Wischnewsky ulcers in the stomach and duodenum and pancreatitis and pancreatic fat necrosis findings in the autopsy are supportive findings for the hypothermia-related deaths [1,6-8]. In addition, there are a number of immunohistochemical, histopathological or biochemical studies on the hypothermia-related mortality diagnosis in the literature [1,6,8-11].
In this study, it was aimed to investigate the frequency of autopsy findings and the frequency of cases decided to die due to hypothermia in Eskişehir, Turkey.

\section{Materials and Methods}

The study was carried out in Eskișehir province in Western Anatolia. Eskisehir is a city in turkey and its population is around 8,00000 . Cases decided to die due to hypothermia as result of forensic investigations and postmortem examinations such as autopsy, toxicological and histopathological examinations in Eskişehir during the 20 year period between 1997 and 2016 were included in the study. During the 20 year period, it was understood that the autopsies were conducted by Eskişehir Forensic Medicine Branch Directorate, Eskişehir Osmangazi University Forensic Medicine Department or physicians affiliated to the Ministry of Health in different periods. All the judicial deaths in the city are sent to our unit ready to work. Therefore, with permission from the Eskişehir Public Prosecutor's Office, the autopsy archive was used where all the dead examinations and autopsies were held. In addition, criminal investigation files were used. All the cases included in the study were autopsied. The cases without autopsy were not included in the study. The cases were evaluated in terms of age, gender, location of the body, month in which the body was found, autopsy findings, psychiatric disease history, toxicological examination and death investigation information. In the 
Page 2 of 4

investigation files examined, there were findings of crime scene investigations, investigation findings of police officers, all depositions of the relatives of the deceased or those who have seen them, and the results of histopathological and toxicological examinations. The data were evaluated using the SPSS 20.0 program. The characteristics of the study group are presented with descriptive statistical data.

\section{Results}

In the 20 -year period covered by the study, 7512 forensic qualified deaths occurred in our province, of which $16(0.2 \%)$ were hypothermia-related deaths. It was determined that all of the cases were male, their ages ranged from 48 to 78 and the mean age was 62.4 \pm 7.2. It was determined that deaths occurred most frequently in January with 8 (50\%) cases. 10 (62.5\%) of the cases were found in open land or street, and 4 (25\%) were found to be in the dwelling. Skin color changes were detected in all cases due to hypothermia in external examinations. Histopathological and toxicological examinations were performed in 12 cases. Autopsy macroscopic examination revealed Wischnewsky ulcers in 11 cases $(68.8 \%)$ due to hypothermia in gastric mucosa. In 6 cases (37.5\%), enzymatic fat necrosis was detected as a result of pancreas histopathologic examination. In 9 cases $(56.3 \%)$ there was a history of psychiatric and neurological disease. Toxicological examination revealed alcohol in quantities ranging from $75 \mathrm{mg} / \mathrm{dl}$ to $238 \mathrm{mg} / \mathrm{dl}$ in 7 cases $(43.8 \%)$. Characteristics of the phenomena are presented in Table 1.

\begin{tabular}{|c|c|c|c|c|c|c|c|c|}
\hline Case & Gender & Age (Years) & Month & Location & Autopsy Findings* & $\begin{array}{l}\text { Psychiatric } \\
\text { Neurological Disease }\end{array}$ & Toxicology & Homeless \\
\hline 1 & Male & 53 & January & Open land & $\mathrm{S}, \mathrm{W}$ & Schizophrenia & - & - \\
\hline 2 & Male & 61 & February & Street & $\mathrm{s}$ & Alzheimer's Disease & $\begin{array}{l}109 \mathrm{mg} / \mathrm{dl} \\
\text { ethanol }\end{array}$ & - \\
\hline 3 & Male & 65 & December & $\begin{array}{l}\text { Abandoned } \\
\text { house }\end{array}$ & $\mathrm{S}, \mathrm{W}$ & $\begin{array}{l}\text { Atypical } \\
\text { +Dementia }\end{array}$ & $\begin{array}{l}75 \mathrm{mg} / \mathrm{dl} \\
\text { ethanol }\end{array}$ & - \\
\hline 4 & Male & 59 & January & Factory store & $S, W, P$ & Unknown & $\begin{array}{l}183 \mathrm{mg} / \mathrm{dl} \\
\text { ethanol }\end{array}$ & + \\
\hline 5 & Male & 57 & January & Open land & $\mathrm{S}, \mathrm{W}$ & Unknown & - & + \\
\hline 6 & Male & 48 & January & Open land & $\mathrm{S}, \mathrm{W}$ & Unknown & $\begin{array}{l}238 \mathrm{mg} / \mathrm{dl} \\
\text { ethanol }\end{array}$ & + \\
\hline 7 & Male & 66 & December & $\begin{array}{l}\text { Abandoned } \\
\text { house }\end{array}$ & $\mathrm{S}, \mathrm{W}, \mathrm{P}$ & Unknown & $\begin{array}{l}207 \mathrm{mg} / \mathrm{dl} \\
\text { ethanol }\end{array}$ & + \\
\hline 8 & Male & 65 & January & Workplace & S,W & Unknown & $\begin{array}{l}112 \mathrm{mg} / \mathrm{dl} \\
\text { ethanol }\end{array}$ & + \\
\hline 9 & Male & 72 & January & $\begin{array}{l}\text { Abandoned } \\
\text { house }\end{array}$ & $\mathrm{S}, \mathrm{P}$ & Unknown & $\begin{array}{l}165 \mathrm{mg} / \mathrm{dl} \\
\text { ethanol }\end{array}$ & + \\
\hline 10 & Male & 75 & February & $\begin{array}{l}\text { Abandoned } \\
\text { house }\end{array}$ & $\mathrm{S}, \mathrm{W}, \mathrm{P}$ & $\begin{array}{l}\text { Atypical } \\
\text { +Dementia }\end{array}$ & - & - \\
\hline 11 & Male & 78 & December & Open land & $\mathrm{s}$ & $\begin{array}{l}\text { Atypical } \\
\text { +Dementia }\end{array}$ & - & - \\
\hline 12 & Male & 63 & January & Open land & $\mathrm{s}$ & $\begin{array}{l}\text { Atypical } \\
\text { +Dementia }\end{array}$ & - & - \\
\hline 13 & Male & 55 & November & $\begin{array}{l}\text { Abandoned } \\
\text { house }\end{array}$ & $\mathrm{S}, \mathrm{W}$ & Unknown & - & + \\
\hline 14 & Male & 57 & January & Street & $S, P$ & Atypical Psychosis & - & - \\
\hline 15 & Male & 60 & December & Open land & $\mathrm{S}, \mathrm{W}$ & Schizophrenia & - & - \\
\hline 16 & Male & 64 & February & Open land & $S, W, P$ & Alzheimer's Disease & - & - \\
\hline
\end{tabular}

Table 1: Characteristics of deaths due to hypothermia.

\section{Discussion}

No studies have been found in our country that give the frequency of mortality associated with hypothermia. A study conducted in Konya has reported 12 deaths due to hypothermia between 2000 and 2008 [5]. Taylor et al. reported the hypothermia-related mortality to be $0.07 \%$ in their study of epidemiology of death events [12], which occurred between 1977 and 1986 in New Zealand due to hypothermia. In our work, all judicial deaths in the 20 year period in Eskişehir were evaluated. The number of all deaths has not been reached. However, the ratio between judicial deaths was determined to be $0.2 \%$. Eskisehir 
is a city where the temperature of the air falls below zero in the winter months and the air flow is significantly higher. Even if the ambient temperature is $10^{\circ} \mathrm{C}$ or lower, it is stated that it is enough to cause fatal hypothermia, but it can be affected by factors such as air movement and humidity [6,13]. Despite the absence of broad-based epidemiologic studies, it is estimated that deaths due to hypothermia in Eskişehir are above the country average in terms of their climate characteristics.

Elderls cannot produce enough heat due to decreased muscle mass or chronic diseases and are exposed to hypotermia more frequently [2,13-16]. People with diseases such as dementia in the elderly or those with psychotic disorders have been reported to be exposed to cold air and fatal hypothermia for a long time outside in situations such as disappearance $[1,2,7,8]$. In our study, it was determined that 6 cases (37.5\%) were over 65 years old, the average age was 62.4 and 9 cases (56.3\%) had diseases that could affect mental health such as psychosis and Alzheimer/dementia. It was understood from the investigation files that these cases had left home for some reason and could not find their homes again.

Hypothermia is a major problem for the homeless [2,17-20]. In the United States, 27 homeless people were reported to have died due to hypothermia in a study evaluating homeless deaths between 2005 and 2010 [18]. In our study, 7 cases [43.8\%] were found to be homeless.

Alcohol increases the risk of hypothermia by decreasing the ability of people to decide to have adequate clothing and to be in appropriate environments for protection from cold as well as increases heat loss by dilatation of superficial veins $[1,13,20,21]$. The function of body heat protection is supplied through the sympathetic system. Vasoconstriction in skin and skeletal muscles is the most important mechanism in the conservation of heat. This mechanism is abolished by alcohol intake at toxic levels $[1,6,20,22]$. There are also studies show that alcohol affects the hypothalamus and impairs heat regulation $[23,24]$. Toxicological examination revealed alcohol in quantities ranging from $75 \mathrm{mg} / \mathrm{dl}$ to $238 \mathrm{mg} / \mathrm{dl}$ in 7 cases (43.8\%).

Cold erythema is a common symptom in people exposed to cold. It is described as dark red discoloration (color change), which is separated from the normal areas around by clear boundaries. Its mechanism is cold-related cellular damage, and the obstruction of the small vessels in the skin. Sometimes the color-changing area may be pink in the peripheral part and darker in the central part. The dark pink areas are found more extensively around the large joints and on the extensor faces of the extremities. The most common places are knee, wrist and hip joints. These are followed by the lower part of the legs, the forearm, the wrist and the front of the hands. Also areas with bluish discoloration in hands, wrists, knees and feet can be seen $[1,3,6,25]$. In our study, cold erythema was present due to hypothermia.

Changes in gastric mucosa are seen in cases of hypothermia-related deaths. Significant ulcers and multiple bleedings can be seen in the stomach. The blood in the mucosa is blackish because of the change in blood. These lesions, as described by Wischnewsky, are expressed as "Wichnewsky spot" $[26,27]$. Possible causes of these stains are thought to be cellular damage caused by submucosal hypoxia, which is secondary to the shift of the oxyhemoglobin dissociation curve to the left and decrease in metabolic rate [1,6,27-29]. It has been reported that the incidence of hypothermia in Wischnevsky ulcers varies between $44 \%-90.9 \%$ [30]. In the present study, Wischnewsky ulcers were detected in 11 cases $(68.8 \%)$ due to hypothermia in the gastric mucosa.

Another organ affected by the hypothermia is the pancreas. In some cases, fatty necrosis areas are associated with haemorrhagic pancreatitis. Although there are many theories about the mechanism of pancreatitis formation, this is not fully understood $[1,6,25]$. In our study, histopathological examination revealed pancreatitis and pancreatic fat necrosis in 6 cases $(37.5 \%)$.

\section{Conclusion}

It has been emphasized in the literature that autopsy findings should not be enough alone, that other causes of death should be excluded, and that they should be supported by forensic investigation and investigation of the scene $[1,5,6,8,16]$. In the present study, autopsy findings and judicial investigation were evaluated together in all cases. However, it was understood that histopathological and toxicological examination was not performed in 4 cases. Histopathologic and toxicological examination is absolutely necessary for the diagnosis of hypothermia related death. In our study with limited number of cases, it was seen that age, homelessness, alcohol use, dementia/Alzheimer's and psychotic disorders affecting consciousness are related to hypothermia-related deaths. Hypothermic deaths are thought to be preventable deaths and the protection of those with mental illness that will affect the consciousness, the homeless and the elderly is thought to diminish the mortality related to hypothermia.

\section{Limitations of the Study}

Because the study was conducted in the form of an archive scan, data may have been lost due to incomplete registrations. Only those cases whose autopsy had been carried out and whose files were completed after the criminal investigation and who were decided to have died as a result of hypothermia were included in the study. 20year mortality statistics of our city could not be reached. For this reason, the ratio of hypothermia deaths to all deaths has not been determined. It was understood that histopathological and toxicological examination was not performed in 4 cases and that these cases were decided as the result of autopsy findings and judicial investigation.

\section{References}

1. Palmiere C, Teresiński G, Hejna P (2014) Postmortemdiagnosis of hypothermia. Int J Legal Med 128: 607-614.

2. Lim C, Duflou J (2008) Hypothermiafatalities in a temperateclimate: Sydney, Australia. Pathology 40: 46-51.

3. Nixdorf-Miller A, Hunsaker DM, Hunsaker JC $3^{\text {rd }}$ (2006) Hypothermia and hyperthermia medicolegal investigation of morbidity and mortality from exposure to environmental temperature extremes. Arch Pathol Lab Med 130: 1297-1304.

4. Ward ME, Cowley AR (1999) Hypothermia: a naturalcause of death. Am J Forensic Med Pathol 20: 383-386.

5. Doğan KH, Esen H, Demirci Ş, Gündoğmuş ÜN (2013) Evaluation of hypothermia-related deaths. General Medicine Derg 23: 1-5.

6. Akçan R, Ylldırım MŞ, Lale A, Heybet ER (2014) Examination of the methods used to identify fatal hypothermia. Forensic Medicine Bulletin 19: $112-120$

7. Turk EE (2010) Hypothermia. Forensic Sci Med Pathol 6: 106-115.

8. Mizukami H, ShimizuK, Shiono H, Uezono T, Sasaki M (1999) Forensic diagnosis of death from cold. Leg Med 1: 204-209. 
9. Zhu BL, Ishikawa T, Michiue T, Li DR, Zhao D, et al. (2007) Postmortem serum catecholamine levels in relation to the cause of death. Forensic Sci Int 173: 122-129.

10. Maeda H, Ishikawa T, Michiue T (2011) Forensic biochemistry for functional investigation of death: Concept and practical application. LegMed (Tokyo) 13: 55-67.

11. Kitamura O, Gotohda T, Ishigami A, Tokunaga I, Kubo S (2005) Effect of hypothermia on postmortem alterations in MAP2 immunostaining in the human hippocampus. LegMed (Tokyo) 7: 24-30.

12. Taylor NA, Griffiths RF, Cotter JD (1994) Epidemiology of hypothermia: fatalities and hospitalisations in New Zealand. Aust N Z J Med 24: 705-710.

13. Lifschutz B, Donoghue E (998) Forensicpathology of heat and cold related injuries. Clin Lab Med 18: 77-90.

14. Centers for Disease Control and Prevention (1996) Hypothermia related deaths-Vermont, October 1994-February 1996. MMWR Morb Mortal Wkly Rep45: 1093-1095.

15. McAlpine C, Dell JLC (1987) Outcome after episodes of hypothermia. Age Ageing 16: 115-118.

16. Taylor AJ, McGwin G Jr, Davis GG, Brissie RM, Holley TD, et al. (2001) Hypothermia deaths in Jefferson County, Alabama. Inj Prev 7: 141-145.

17. Suzuki H, Hikiji W, Tanifuji T, Abe N, Fukunaga T (2013) Medicolegal death of homeless persons in Tokyo Metropolisover 12 years (1999-2010). Leg Med (Tokyo) 15: 126-133.

18. Gambatese M, Marder D, Begier E, Gutkovich A, Mos R, et al. (2013) Programmatic impact of 5 years of mortality surveillance of New York City homeless populations. Am J Public Health 103: 193-198.

19. Erkalp K, Yangin Z, Başaranoğlu G, Erden V (2006) Accidental hypothermia (a case report). Ulus Travma Acil Cerrahi Derg 12: 249-253.

20. Caroselli C, Gabrieli A, Pisani A, Bruno G (2009) Hypothermia: an under-estimated risk. Intern Emerg Med 4: 227-230.
21. Jones AW (2011) Fatality from drinking denatured alcohol and hypothermia. J Anal Toxicol 35: 316-318.

22. Özüçelik OP (2002) Environmental accents. In: Poisoning, Akkan G (editor). İstanbul University Cerrahpaşa Medical Faculty, Continuous Medical Education Activities Symposium, Series Publication Istanbul, Turkey pp: 132-146..

23. Westerman AT, Roma PG, Price RC, Dominguez JM (2010) Assessing the role of the medial preoptic area in ethanol-induced hypothermia. Neurosci Lett 475: 25-28.

24. Arican N, Kaya M, Yorulmaz C, Kalayci R, Ince H, et al. (2006) Effect of hypothermia on blood-brain barrier permeability following traumatic brain injury in chronically ethanol-treated rats. Int J Neurosci 116: 1249-1261.

25. Soysal Z, Eke M, Cagdır S (1999) Forensic autopsy. Volume II. İstanbul University Cerrahpaşa Medical Faculty Publications, Istanbul, Turkey.

26. Tsokos M, Rothschild MA, Madea B, Rie M, Sperhake JP (2006) Histological and immunohistochemical study of Wischnewskyspots in fatal hypothermia. Am J Forensic Med Pathol 27: 70-74.

27. Selçuk Ç, Nursel Türkmen Y, Filiz E, Bülent E, Halis D (2015) Wischnewsky spots in fatal hypothermia: Case Report. Maedica (Buchar) 10: $280-282$.

28. Brandstrom H, Eriksson A, Giesbrecht G, Angquist KA, Haney M (2012) Fatal hypothermia: An analysis from a sub-arcticregion. Int J Circumpolar Health 71: 1-7.

29. Clark KH, Stoppacher R (2016) Gastric mucosal petechial hemorrhages (WischnewskyLesions), hypothermia, and diabetic ketoacidosis. Am J Forensic Med Pathol 37: 165-169.

30. Preuss J, Thierauf A, Dettmeyer R, Madea B (2007) Wischnewsky's spots in an ectopic stomach. Forensic Sci Int 169: 220-222. 